framework of his treatise in such a manner that the architecture should place no difficulties in the way of ordinary students. We have, first, the Forms of Gonorrhoea; secondly, the Seat of Gonorrhoa; thirdly, the Causes of Gonorrhoa, in which section we would particularly direct the notice of the student to the remarks on the "Syphilitic Sore in the Urethra," (p. 19.) In this section (p. 28), the remarks upon the "menstrual secretion" as a cause of gonorrhœa, are particularly valuable; as also those upon the noxious qualities of the secretions of some females, (p. 31.) The Treatment of Gonorrhoea occupies the next division of the work, and to this portion our remarks have been particularly directed above. The Consequences of Gonorrhea, together with a short disquisition on Gonorrhœa in the Female, form the conclusion of the treatise.

In concluding the notice of a work which we cannot but think is destined to become a classic, we cannot refrain from congratulating the author upon the adoption of a style which, at the same time that it is thoroughly English, lucid, and scientific, is vigorous and satisfactory. It would be difficult to find a book in which "cases" are described so tersely and yet so completely. With the quotation of one, we conclude our notice.

"A young man in the Lock Hospital had a cachectic bubo, ulcerated, and in a chronic state. The surgeon pared the edges of the ulcer with a scalpel. Phagedæna immediately ensued-it extended widely, deeply, and fast-the femoral artery was laid bare and seen pulsating fearfully at the bottom of the spreading sore. I was house-surgeon at the time, and, apprehensive of what would occur, I set a nurse and an assistant to watch this patient exclusively. I had paid my morning visit, and was quitting the ward, when a shout recalled me. The artery had given way. I shall never forget the scene. The nurse had her hands in the wound, from which the blood was issuing in gushes, every one of which seemed death. With a presse-artere which was ready, I instantly arrested the circulation through the vessel, on the pubic bone, and then stuffed the wound with lint. Pressure in both places was kept up by relays of assistants, for three or four days and nights. The patient at the same time was plied with brandy, wine, and opium. He was saved. A clot formed, the phagedæna was arrested, and the wound cicatrized. I have met him more than once since, and he has continued strong and hearty. The flow of blood appears to be uninterrupted through the femoral trunk. In all my professional life I have never seen another such escape from imminent destruction. Whoever witnessed it would pause before he meddled with a cachectic bubo." - (p. 260.)

Would that all cases of the like importance were described as graphically, and with as little circumlocution, as this!

\section{Nrem Enbentínis}

$$
\text { IN AID OF THE }
$$

\section{PRACTICE OF MEDICINE AND SURGERY.}

\section{New Portable Hydro-Electric Chain Battery.}

This is a new invention, consisting of a perfect galvanic battery, in the form of a chain, which is contained in a morocco box, the ordinary size of a pocket-book, invented by Pulvermacher, of Vienna, and manufactured in this country by Mr. Meinig, of Leadenhall-street.

It contains the whole metallic combination of a voltaic pile, being composed of copper and zinc wire, wound round grooved pieces of wood, requiring only its immersion for a moment in dilute acetic acid, to produce most powerful galvanic action for two or three hours; a re-immersion at the termination of that period continues its power. There is connected with it a small clock-work, which makes and breaks contact in a most perfect manner.

The advantages which the medical practitioner can obtain from an instrument in so small a compass as to be able to carry it in his pocket, cannot be too highly esteemed, enabling him, as it does, to apply galvanism in the quickest and most efficient manner to any part of the human frame; thus superseding the cumbrous battery now in general use for therapeutic purposes. There are also smaller chains, which may be worn round the body or limbs, the ends reguiring to be fixed by means of two buckles to an elastic band, so that a current of a mild and continuous nature can be passed through any part wished. By this arrangement the long-desired continuous current, of a mild nature, is obtained, instead of the more acute effect of the direct shock, which in many cases would be prejudicial.

It is probable that the apparatus will render galvanism of much benefit as a curative process.

This invention really merits the warmest commendations.

\section{REPLACING A PARTIALLY ABORTED FOETUS.}

\section{To the Editor of THe LaNCET.}

SIR,-A few months ago I was induced to make some observations upon the plan of treatment proper in parturition accompanied with procidentia nteri; the case, therefore, extracted by your correspondent Mr. J. Henning, from Bartholin, of a supposed return within the uterus of an almost completed abortion, at the 13th week, the patient continuing to carry the child the full nine months, and then falling into natural labour, has attracted my attention, and I intrude upon your valuable space for a few observations.

It is well known that the works of Bartholin, Stalpartius, Borellus, and other old authors, nay, even the earlier volumes of our own Philosophical Transactions, abound in histories the truth of which is very problematical.

This story related by Bartholin gives neither the name of the woman, her abode, nor the date of the occurrence, a strong reason for believing it to be apocryphal, but there is one internal evidence of correctness which Mr. Henning has not noticed-viz. that in accordance with the customs of those days, the so-called embryo was replaced by a midwife (obstetrix) at the suggestion of the empiric. If, on this ground, we assume some part of the narration to be true, to what does it amount? Simply this, that the mother, while straining to lift the heavy bucket of ale, forced down the uterus to the vulva, and that the cervix uteri was mistaken by the empiric and midwife, neither of whom we may be sure ever studied anatomy, for an immature foetus. It was, in fact, nothing more than a slight increase of a not unusual occurrence in the early period of utero-gestation.

There is, however, a very curious case of a somewhat similar character, related by Louisa Bourgeois, the celebrated midwife to the Queen of the French king, Henry IV., in the early part of the 17th century, and which, extraordinary as it is, can hardly be disbelieved by the most scrupulous reader, so circumstantially is it narrated. The substance of the history is briefly as follows:-Madame Bourgeois "knew a surgeon named Philippe Baudoin, living at Cherebourg, in Lower Normandy, who had in his youth served the late Ambroise Paré; this surgeon saw a woman named Fleurye Gardin, wife of Richard Feré, of the parish of Toulenast, near Cherebourg, to whom it happened, on Christmas day, while at church, a quarter of a league from her home, that the child, of which she was pregnant during six months and a half, passed its arm ont of her body. She was taken home, where the child withdrew the arm, and waited to be born (demeura d'accoucher) till the beginning of March, when she was naturally delivered of a son, who was baptized, and lived one day." Madame Bourgeois remarks that "this is a strange thing, and one which possibly would not happen in a hundred years, (qui est une chose estrange, et qui possible n'arriveroit en cent ans,)" and then proceeds to explain how it might occur.

Her reasoning is far from clear, but if we bear in mind the idea then universally prevailing, that the child sat upright in the womb, and only a few days or hours before birth performed the "culbute," or turned round so as to present by the head, we may comprehend her reasoning to be as follows: That the child, " being attacked by colic, trom the cold which the mother had endured, caused" some "loose membranes near to the placenta, where his hand was, to break; that the waters were retained by the bag of membranes lower down, and that the chilled arm and hand, being warmed by the bed, were withdrawn." This, in the language of the present day, can only be construed as indicating that, by some curious and very unusual uterine action, the child was partially propelled into the vagina, so that the arm protruded from the body within the bag of membranes, and that the quiet enforced on the patient's reaching home, allowed the uterus to receive again the partially expelled ovum, and to retain it until the usual period of parturition.-I am, Sir, your obedient servant, Brook-street, Aug. 22, 1851. $\quad$ S. W. J. Merniman, M.D. 